\title{
Analisis Hasil Uji Pembangkit Listrik Hybrid Turbin Angin 1kWh Dan Panel Surya 100 WP
}

\author{
Hastuti Azis ${ }^{1}$; Pawenary²; Meyhart Sitorus ${ }^{3}$ \\ 1,2,3 Sekolah Tinggi Teknik PLN \\ ${ }^{1}$ hastuti@sttpln.ac.id \\ 2pawenary@sttpln.ac.id \\ ${ }^{3}$ bangkit@sttpln.ac.id
}

\begin{abstract}
Electrification ratios in some isolated regions and scattered islands in Indonesia are still very low. Until now, most of the electricity needs in Indonesia are still supplied by Diesel Power Plants (PLTD) that use fossil energy as their main fuel. There fore, the use of renewable energy is needed as one of the steps in meeting electricity needs. In this study will be studied about Hybrid Power Generators that utilize wind energy or wind using low speed turbine hybrid by utilizing solar energy using solar panels as an alternative to meet the needs of electrical energy in isolated areas and islands outermost in Indonesia. Testing is done on a small scale. The results obtained from the efficiency of the hybrid system are still less than 30\%, namely $11.2 \%$ which shows poor performance. The total electricity produced per day is $2.7 \mathrm{kWh}$.
\end{abstract}

Keywords: Renewable energy, low speed turbin, solar panel

\begin{abstract}
ABSTRAK
Rasio elektrifikasi di beberapa wilayah terisolir dan pulau - pulau terpencar di Indonesia masih sangat rendah. Sampai saat ini, sebagian besar kebutuhan listrik di wilayah Indonesia tersebut masih dipasok oleh Pembangkit Listrik Tenaga Diesel (PLTD) yang menggunakan energi fosil sebagai bahan bakar utamanya. Hal ini mengakibatkan perlu adanya pemanfaatan energi terbarukan sebagai salah satu langkah dalam pemenuhan kebutuhan energi listrik. Dalam penelitian ini akan dikaji mengenai Pembangkit Listrik Hybrid yang memanfaatkan energi angin atau bayu menggunakan turbin angin keceptan rendah (low speed turbine) digabung atau hybrid dengan memanfaatkan energi surya menggunakan panel surya sebagai alternatif pemenuhan kebutuhan energi listrik di wilayah - wilayah terisolir dan pulau- pulau terluar di Indonesia. Pengujian dilakukan dalam skala kecil. Hasil penelitian mendapatkan dari efisiensi system hybrid masih kurang dari 30\% yaitu 11,2\% yang menunjukkan performa kurang baik. Total energi listrik yang dihasilkan perhari adalah $2.7 \mathrm{kWh}$.
\end{abstract}

Kata kunci: Renewable energy, low speed turbin, panel surya 


\section{PENDAHULUAN}

Energi listrik merupakan kebutuhan dasar manusia yang terus meningkat sejalan dengan tingkat kesejahteraannya. Di Indonesia, Rasio Elektrifikasi di beberapa daerah masih sangat rendah terutama pada daerah-daerah terpencil di Indonesia bagian Timur. Berdasarkan data rasio elektrifikasi tahun 2015, Rasio Elektrifikasi di Sulawesi tenggara sebesar 68,84 \%, Nusa tenggara Timur sebesar 58,4 \% dan Papua sebensar 45,93\%. Pelaksanaan elekrifikasi di desa - desa terpencil baik yang terisolir, pulau - pulau terpencar, maupun daerah perbatasan memang relatif lebih sulit dibandingkan kawasan yang lebih "berkembang". Hal ini diakibatkan oleh minimnya data penduduk, sulitnya transportasi dan rendahnya kepadatan penduduk.

Di satu sisi, perubahan lingkungan terutama pemanasan global yang semakin hari semakin mengurangi kualitas daya dukung lingkungan, memaksa kita untuk mulai mencari pembangkit energi dengan bahan bakar alternatif non-fosil. PLTMH (Pembangkit Listrik Tenaga Mikro Hidro) yang memanfaatkan aliran air sungai dan air terjun cukup banyak ditemukan di Indonesia. PLTS (Pembangkit Listrik Tenaga Surya) menjadi pilihan terdepan dengan memanfaatkan potensi letak geografis Indonesia di daerah katulistiwa. Kemudian dengan potensi kecepatan angin yang memadai, angin bisa juga dimanfaatkan sebagai energi terbarukan untuk memproduksi energi listrik khususnya bagi kalangan rumah tangga.

Tujuan dari penelitian ini adalah memberikan gambaran umum mengenai hasil uji pembangkit listrik hybrid turbin angin $1 \mathrm{kWh}$ dan Panel surya $100 \mathrm{Wp}$. Tujuan lainnya adalah untuk mengetahui kelayakan teknis dan finansial pembangkit listrik hybrid turbin angin 1 $\mathrm{kWh}$ dan panel surya $100 \mathrm{Wp}$. Manfaat yang dari penelitian ini adalah hasil dari penelitian ini diharapkan dapat memberikan kontribusi terhadap pemerintah maupun PLN terkait rencana peningkatan Rasio Elektifikasi melalui penerapan teknologi energi terbarukan di wilayah - wilayah terpencil dan pulau - pulau terpencar di Indonesia dengan memanfaatkan pembangkit listrik hybrid turbin angin $1 \mathrm{kWh}$ dan panel surya $100 \mathrm{Wp}$. Selain itu hasil dari penelitian ini diharapkan dapat memberikan gambaran kelayakan pembangkit listrik hybrid turbin angin $1 \mathrm{kWh}$ dan panel surya $100 \mathrm{Wp}$ sebagai pilihan bagi PLN untuk meningkatan Rasio Elektifikasi di Indonesia selain PLTD yang harga rupiah/kWh relatif mahal dan mengkonsumsi BBM yang berasal dari luar negeri (impor).

Yang menjadi pembahasan dalam Penelitian ini adalah bagaimana cara turbin angin kecepatan rendah tipe AWI-E1000T dan NT500W untuk meningkatkan rasio Elektrifikasi. Minimal dapat digunakan sebagai alternatif lain untuk memasok litrik pada wilayah wilayah terpencil dan pulau - pulau tersebar di Indonesia. Permasalahan dalam penelitian ini dibatasi pada data yang digunakan dalam penelitian ini adalah data hasil uji pembangkit listrik hybrid turbin angin $1 \mathrm{kWh}$ dan panel surya $100 \mathrm{Wp}$ untuk menghitung kecepatan dan kerapatan angin nasional tahun 2015.

Dewasa ini dan beberapa tahun ke depan, manusia masih akan tergantung pada sumber energi fosil karena sumber energi inilah yang manpu memenuhi kebutuhan energi manusia dalam skala besar. Sedangkan sumber energi alternatif / terbarukan belum dapat memenuhi kebutuhan energi manusia dalam skala besar karena fluktuasi potensi dan tingkat perekonomian yang belum bisa bersaing dengan energi konvensional. Di lain pihak, manusia dihadapkan pada situasi menipisnya cadangan sumber energi fosil dan meningkatnya kerusakan lingkungan akibat penggunaan energi fosil. 
Matahari merupakan sumber energi terbesar yang diketahui saat ini. Radiasi matahari yang sampai ke permukaan bumi ada yang diserap dan ada yang dipantulkan. Perubahan letak matahari terhadap bumi akan menyebabkan intensitas radiasi surya yang tiba di permukaan bumi juga berubah-ubah. Berkaitan dengan hal tersebut di atas, radiasi surya yang tiba pada suatu tempat di permukaan bumi dapat kita bedakan menjadi 3 jenis. Ketiga jenis radiasi tersebut adalah : radiasi langsung (direct radiation), radiasi sebaran (diffuse radiation), radiasi pantulan (reflection radiation). Pada penelitian ini radiasi yang akan diukur adalah radiasi langsung (direct radiation). Intensitas radiasi ini akan diukur menggunakan alat ukur actinography. Cahaya matahari terdiri atas foton atau partikel energi surya, dimana foton inilah yang dikonversi menjadi energi listrik. Foton-foton mengandung energi yang bervariasi menurut panjang gelombangnya. Energi foton yang diserap oleh sel surya diserahkan sebagian atau seluruhnya kepada elektron di dalam sel surya. Dengan adanya energi baru ini maka elektron mampu lepas dari posisi normalnya terhadap atom sehingga menjadi arus dalam suatu sirkuit listrik.

Berdasarkan data dari Dewan Energi Naional, potensi Energi matahari di Indonesia mencapai rata - rata 4,8 kiloWatt hour per meter persegi per hari $\left(\mathrm{kW} / \mathrm{m}^{2} /\right.$ hari), setara $112.000 \mathrm{GWp}$ jika di bandingakan dengan luasan lahan di Indonesia atau sepuluh kali lipat dari potensi Jerman dan Eropa.

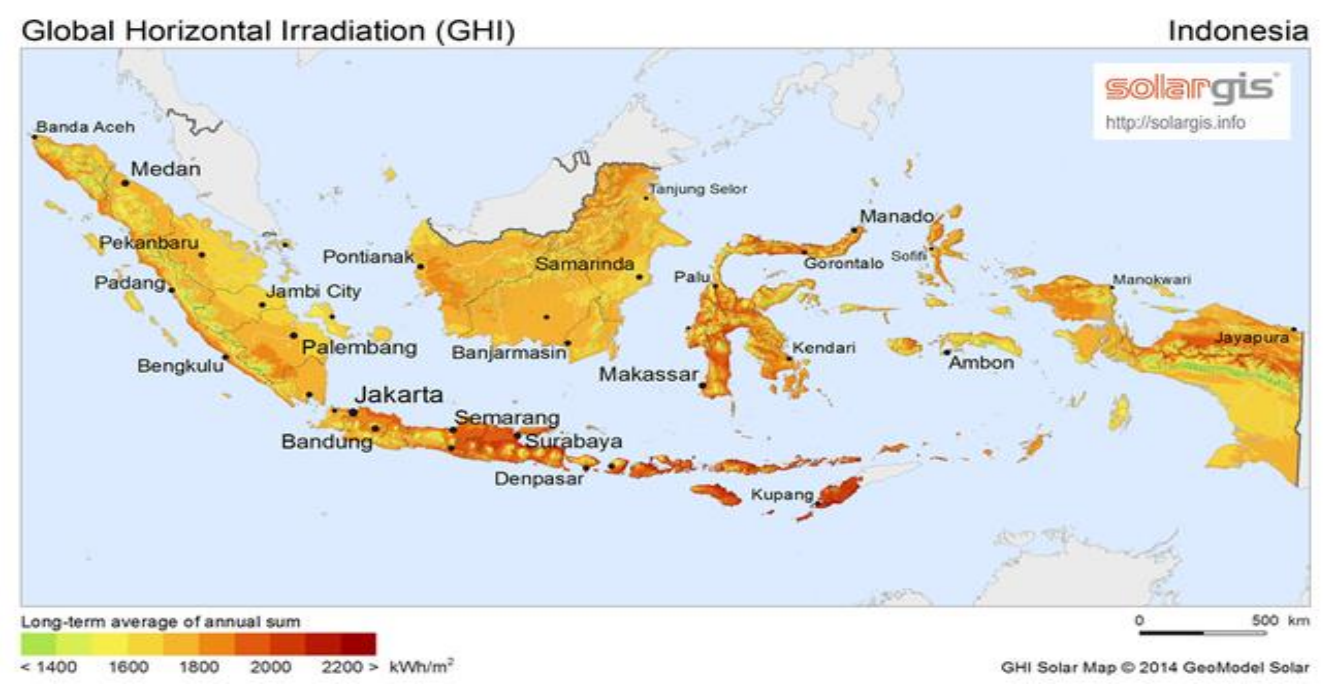

Gambar 1. Peta Potensi Energi Matahari Indonesia

Pembangkit Listrik Tenaga Surya (PLTS) adalah pembangkit listrik yang mengubah energi surya menjadi energi listrik. Pembangkitan listrik bisa dilakukan dengan dua cara, yaitu secara langsung menggunakan fotovoltaik dan secara tidak langsung dengan pemusatan energi surya. Fotovoltaik mengubah secara langsung energi cahaya menjadi listrik menggunakan efek fotoelektrik. Pemusatan energi surya menggunakan sistem lensa atau cermin dikombinasikan dengan sistem pelacak untuk memfokuskan energi matahari ke satu titik untuk menggerakan mesin kalor. Complete set solar panel terdiri dari beberapa komponen utama seperti Solar Panel, Voltage Regulator, Charger, Inverter dan Battery. panel solar harus mampu mengalirkan tegangan lebih besar dari tegangan kerja baterai, jika menggunakan sistem baterai 12 volt, maka keluaran solar cell paling tidak harus 13-14 volt $(+/ 110 \%)$. 
Angin merupakan udara yang bergerak yang terjadi karena adanya perbedaan suhu antara udara panas dan udara dingin. Adanya perbedaan suhu udara ini karena adanya perbedaan tekanan udara di permukaan bumi. Udara bergerak dari daerah yang memiliki tekanan udara yang tinggi ke daerah yang memiliki tekanan udara yang rendah. Pada dasarnya angin yang bertiup di permukaan bumi terjadi karena adanya penerimaan radiasi surya yang tidak merata di permukaan bumi, sehingga mengakibatkan perbedaan suhu udara [1]. Pertukaran panas pada atmosfer akan terjadi secara konveksi. Berat jenis dan tekanan udara yang disinari cahaya matahari akan lebih kecil dibandingkan jika tidak disinari. Perbedaan berat jenis dan tekanan inilah yang akan menimbulkan adanya pergerakan udara [2].

Angin diberi nama sesuai dengan dari arah mana angin datangnya. Misalnya angin timur adalah angina yang datang dari arah timur, angin laut adalah angin dari laut ke darat, dan angina lembah adalah angin yang datang dari lembah menaiki gunung. Angin lokal disebabkan perbedaan tekanan lokal dan juga dipengaruhi topografi, gesekan permukaan disebabkan gunung, lembah dan lain - lain. Variasi harian disebabkan perbedaan temperatur antara siang dan malam. Perbedaan temperatur daratan dan lautan juga mengakibatkan angin sepoi - sepoi, bagaimanapun angin tidak mengalir sangat jauh di daratan [3].

Arah angin adalah arah dari mana angin berhembus atau dari mana arus angin datang dan dinyatakan dalam derajat yang ditentukan dengan arah perputaran jarum jam dan dimulai dari titik utara bumi dengan kata lain sesuai dengan titik kompas. Umumnya arus angin diberi nama dengan arah darimana angin tersebut berhembus. Misalnya angin yang berhembus dari utara dinamakan angin utara. Kecepatan angin adalah kecepatan dari menjalarnya arus angin dan dinyatakan dalam knot atau kilometer per jam maupun dalam meter per detik [4].

Potensi energi angin Indonesia umumnya berkecepatan lebih dari 5 meter per detik (m/detik). Hasil pemetaan Lembaga Penerbangan dan Antariksa Nasional (Lapan) pada 120 lokasi menunjukkan beberapa wilayah memilik kecepatan angin di atas $5 \mathrm{~m} /$ detik, masing - masing Nusa Tenggara Timur, Nusa Tenggara Barat, Sulawesi Selatan dan Pantai Selatan Jawa. Adapun kecepatan angin $4 \mathrm{~m} /$ detik hingga $5 \mathrm{~m} /$ detik tergolong skala menengah dengan potensi kapasitas 10 - 100 kilowatt. Hal ini dapat dilihat dari Gambar 2 peta potensi angin Indonesia dibawah:

\section{PETA POTENSI ANGIN INDONESIA}

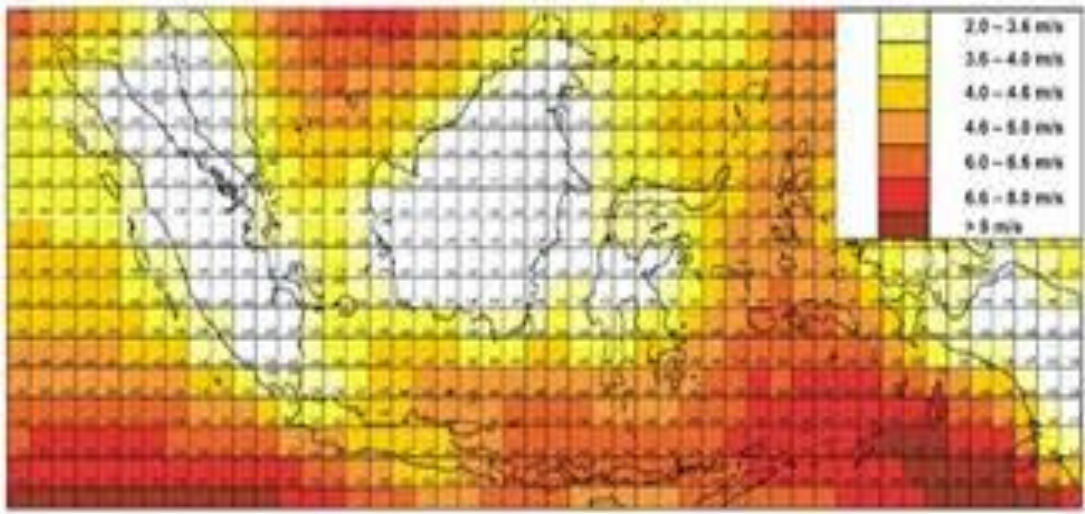

Gambar 2. Peta potensi angin Indonesia (BKPM 2011) [5] 
PLTBayu adalah pembangkit yang memanfaatkan tenaga angin untuk menghasilkan energi listrik. Secara umum konfigurasi utama turbin angin poros datar terdiri dari: rotor ( blade dan hub), nasel/nacelle, generator, transmisi gearbox, kopling, rem, sistem orientasi (yaw system), tower, control system dan pondasi.

Turbin angin bekerja berkebalikan dengan kipas angin (bukan menggunakan listrik untuk menghasilkan listrik, namun menggunakan angin untuk mengahasilakn listrik). Kemudian angin akan memutar sudut turbin, lalu diteruskan untuk memutar rotor pada generator pada bagian belakang turbin angin. Generator mengubah enrgi gerak menjadi energi listrik dengan teori elektro magnetik, yaitu poros pada generator dipasang dengan material ferromagnetik permanen. Setelah itu disekeliling poros terdapat stator yang membentuk fisisnya adalah kumparan - kumparan kawat yang berbentuk loop. Ketika poros generator mulai berputar maka akan terjadi perubahan fluks pada stator yang akhirnya karena terjadi prubahan fluks ini maka dihasilkan tegangan dan arus listrik tertentu.

\section{METODE/PERANCANGAN PENELITIAN}

Dalam melakukan penelitian Analisis Hasil Uji Pembangkit Listrik Hybrid Turbin Angin $1 \mathrm{kWh}$ Dan Panel Surya $100 \mathrm{Wp}$, yang menjadi fokus penelitian adalah seberapa layak performa Pembangkit Listrik Hybrid Turbin Angin 1 kWh Dan Panel Surya 100 Wp baik dari teknis maupun finansial jika di implementasikan penggunaannya secara nyata untuk mememenuhi kebutuhan sehari - hari energi listrik masyarakat di wilayah terpencil. Penelitian ini dilakukan di Di PT Sinergi Nanotech Indonesia, R\&D Office Gd, 110, yang terletak di Jl. Raya Puspitek, Muncul, Serpong, Kota Tangerang selatan, Banten 15314. Penelitian ini berlangsung dalam jangka waktu intensif dalam kurun waktu dari bulan September 2018 sampai dengan Desember 2019. Dalam melakukan penelitian data bersumber dari pengukuran yang dilakukan secara langsung di lokasi penelitian, yaitu data keceptan angin di daerah tersebut, data tegangan dan arus yang dihasilkan dari turbin ke penyimpanan (baterai), data tegangan dan arus keluaran dari penyimpanan (baterai) ke beban, dan data besarnya beban.

Data yang telah tersedia akan dianalisis dengan metode kualitatif. Metode kualitatif digunakan untuk menjelaskan perkembangan data serta analisis secara deskriptif. Flowchart penelitian seperti Gambar 3. 


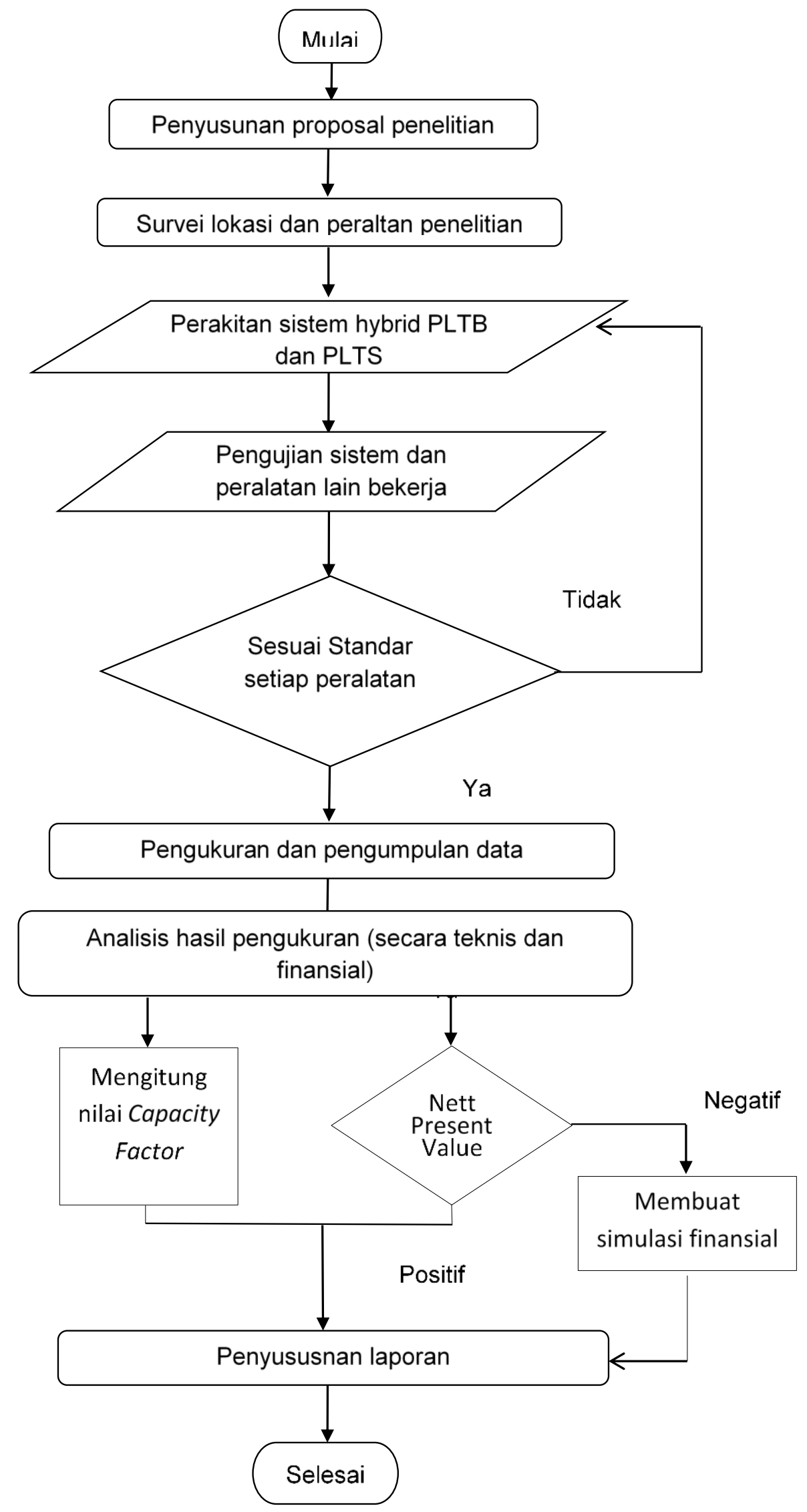

Gambar 3. Flow cart metode penelitian 
Vol. 9, No. 1, Juni 2019, P-ISSN 2356-1505, E-ISSN 2656-9175

https://doi.org/10.33322/sutet.v9i1.384

\section{HASIL DAN PEMBAHASAN}

\subsection{Data Hasil Pengukuran dan Performa PLTB}

Tabel 1. Hasil Pengukuran Produksi Rata-rata Dan uji performa PLTB

\begin{tabular}{|c|c|c|c|c|c|c|c|c|}
\hline No & Tanggal & $\begin{array}{c}\text { Kecepatan } \\
\text { Angin (m/s) }\end{array}$ & $\begin{array}{c}\text { Arus I } \\
\text { (amp) }\end{array}$ & $\begin{array}{c}\text { Tegangan } \\
\text { V(Volt) }\end{array}$ & cos $\boldsymbol{}$ & $\begin{array}{c}\text { Daya } \mathbf{P} \\
\text { (watt) }\end{array}$ & KWh & Efesiensi \\
\hline $\mathbf{1}$ & $01 / 11 / 2018$ & 2.4 & 0.65 & 220.00 & 0.716 & 102.33 & 2.354 & $9.808 \%$ \\
\hline $\mathbf{2}$ & $02 / 11 / 2018$ & 2.4 & 0.65 & 225.17 & 0.704 & 103.00 & 2.369 & $9.870 \%$ \\
\hline $\mathbf{3}$ & $03 / 11 / 2018$ & 2.4 & 0.65 & 211.40 & 0.768 & 105.50 & 2.427 & $10.112 \%$ \\
\hline $\mathbf{4}$ & $12 / 11 / 2018$ & 2.8 & 0.77 & 212.00 & 0.792 & 116.00 & 2.846 & $11.858 \%$ \\
\hline $\mathbf{5}$ & $13 / 11 / 2018$ & 2.8 & 0.77 & 212.00 & 0.792 & 116.00 & 2.846 & $11.858 \%$ \\
\hline $\mathbf{6}$ & $14 / 11 / 2018$ & 4.0 & 0.96 & 212.00 & 0.772 & 105.50 & 2.943 & $12.26 \%$ \\
\hline $\mathbf{7}$ & $22 / 11 / 2018$ & 3.0 & 0.65 & 219.00 & 0.717 & 102.00 & 2.346 & $9.775 \%$ \\
\hline $\mathbf{8}$ & $23 / 11 / 2018$ & 4.0 & 0.96 & 216.00 & 0.772 & 105.50 & 2.943 & $12.26 \%$ \\
\hline $\mathbf{9}$ & $27 / 11 / 2018$ & 3.0 & 0.65 & 220.00 & 0.713 & 102.00 & 2.346 & $9.775 \%$ \\
\hline $\mathbf{1 0}$ & $28 / 11 / 2018$ & 3.0 & 0.65 & 220.00 & 0.713 & 102.00 & 2.346 & $9.775 \%$ \\
\hline
\end{tabular}

\subsection{Data Hasil Uji Pengukuran dan Performa PLTS}

Tabel 2. Hasil Pengukuran Produksi Rata2 Dan uji performa PLTS

\begin{tabular}{|c|c|c|c|c|c|c|}
\hline Waktu & \multicolumn{5}{|c|}{ Measured Value } & \multicolumn{2}{c|}{ Calculated Value } \\
\hline Tanggal & Length $(\mathbf{m m})$ & $\begin{array}{c}\text { Width } \\
(\mathbf{m m})\end{array}$ & $\begin{array}{c}\text { Irradiance } \\
\left(\mathbf{k W} / \mathbf{m}^{2} / \text { day }\right)\end{array}$ & $\begin{array}{c}\text { Active } \\
\text { Energy }(\mathbf{W h})\end{array}$ & $\begin{array}{c}\text { Active } \\
\text { energy }(\mathrm{Wh})\end{array}$ & Effeciency \\
\hline $01 / 11 / 2018$ & 1005.00 & 665.00 & 4.66 & 326.00 & 3114.395 & $10.468 \%$ \\
\hline $02 / 11 / 2018$ & 1005.00 & 665.00 & 4.54 & 317.62 & 3034,337 & $9.553 \%$ \\
\hline $03 / 11 / 2018$ & 1005.00 & 665.00 & 4.60 & 321.80 & 3074.270 & $9.553 \%$ \\
\hline $12 / 11 / 2018$ & 1005.00 & 665.00 & 4.66 & 326.00 & 3114.395 & $10.468 \%$ \\
\hline $13 / 11 / 2018$ & 1005.00 & 665.00 & 4.59 & 321.10 & 3067.583 & $9.556 \%$ \\
\hline $14 / 11 / 2018$ & 1005.00 & 665.00 & 6.14 & 473.00 & 4103.516 & $11.527 \%$ \\
\hline $22 / 11 / 2018$ & 1005.00 & 665.00 & 6.00 & 462.00 & 4008.085 & $11.526 \%$ \\
\hline $23 / 11 / 2018$ & 1005.00 & 665.00 & 6.12 & 471.00 & 4086.165 & $11.526 \%$ \\
\hline $27 / 11 / 2018$ & 1005.00 & 665.00 & 6.10 & 469.00 & 4068.814 & $11.526 \%$ \\
\hline $28 / 11 / 2018$ & 1005.00 & 665.00 & 6.11 & 470.00 & 4077.500 & $11.527 \%$ \\
\hline
\end{tabular}




\subsection{Data Hasil Pengukuran pembangkit Hybrid PLTB dan PLTS}

Tabel 3. Hasil Pengukuran Produksi Rata2 Dan uji perform PLT Hybrid

\begin{tabular}{|c|c|c|c|c|c|c|c|}
\hline No & Tanggal & $\begin{array}{l}\text { Kecepatan } \\
\text { Angin }(\mathrm{m} / \mathrm{s})\end{array}$ & $\begin{array}{c}\text { Irradiance } \\
\left(\mathrm{kW} / \mathrm{m}^{2} / \text { day }\right)\end{array}$ & $\begin{array}{c}\text { Tegangan } \\
\mathrm{V} \text { (Volt) }\end{array}$ & $\begin{array}{c}\text { Daya P } \\
\text { (watt) }\end{array}$ & KWh & Efesiensi \\
\hline 1 & $01 / 11 / 2018$ & 2.4 & 4.76 & 220.00 & 150.33 & 2.489 & $10.37 \%$ \\
\hline 2 & $02 / 11 / 2018$ & 2.4 & 4.50 & 219.00 & 150.69 & 2.496 & $10.40 \%$ \\
\hline 3 & 03/11/2018 & 2.4 & 4.50 & 211.40 & 152.34 & 2.522 & $10.51 \%$ \\
\hline 4 & $12 / 11 / 2018$ & 2.8 & 4.76 & 212.00 & 155.00 & 2.567 & $10.70 \%$ \\
\hline 5 & $13 / 11 / 2018$ & 2.8 & 4.69 & 212.00 & 155.00 & 2.567 & $10.70 \%$ \\
\hline 1 & $14 / 11 / 2018$ & 4.0 & 6.15 & 212.00 & 152 & 2.653 & $11.05 \%$ \\
\hline 2 & $22 / 11 / 2018$ & 3.0 & 6.07 & 219.00 & 155 & 2.884 & $12.02 \%$ \\
\hline 3 & $23 / 11 / 2018$ & 4.0 & 6.14 & 216.00 & 151 & 2.564 & $10.68 \%$ \\
\hline 4 & $27 / 11 / 2018$ & 3.0 & 6.11 & 220.00 & 153 & 2.790 & $11.63 \%$ \\
\hline 5 & $28 / 11 / 2018$ & 3.0 & 6.12 & 220.00 & 150 & 2.550 & $10.63 \%$ \\
\hline
\end{tabular}

Hasil ketiga uji performa dinilai sudah dapat memberikan gambaran tentang karakteristik performa dari sistem pembangkit listrik hybrid turbin angin dan panel surya skala kecil. Untuk lebih menggambarkan karakteristik performa, grafik di bawah menjelaskan rata - rata efisiensi yang dihasilkan oleh tiap turbin angin pada setiap uji performa.

Dari Hasil Uji terlihat jelas bahwa terdapat perbedaan signifikan antara daya keluaran turbin dari turbin angin yang dipasang Pada keceptan tertinggi yaitu $4.0 \mathrm{~m} / \mathrm{s}$ dengan keceptan terendah $2.4 \mathrm{~m} / \mathrm{s}$. Daya keluara turbin angin yang dengan kcepatan angin $4.0 \mathrm{~m} / \mathrm{s}$ lebih besar dibanding turbin angin di daya keluaran sistem pada kecepatan $2.4 \mathrm{~m} / \mathrm{s}$.

Efisiensi turbin angin yang digunakan pada penelitian kali ini, berkisar antara $11 \%$ $13 \%$. Hal ini menunjukan bahwa turbin yang digunakan belum cukup baik. Efisiensi dari turbin angin menunjukan bahwa tidak seluruh energi angin dapat diserap oleh turbin angin. Sebagian energi dikonversikan menjadi bentuk energi lain, seperti energi panas yang timbul karena gesekan.

Hasil akhir dari pengujian ini diharapkan dapat menunjukan seberapa besar energi yang dapat dihasilkan dalam sistem ini dalam kurun waktu sehari. Hal ini diharapkan dapat menjadi acuan kelayakan dari pemanfaatan sistem pembangkit listrik hybrid turbin angin dan panel surya sebagai solusi kelangkaan listrik di daerah - daerah terpencil di Indonesia. Tabel di bawah ini menunjukan daya yang dapat dihasilkan dari sistem ini.

Dapat terlihat pada Tabel 4. bahwa total energi yang dapat dihasilkan oleh sistem pembangkit listrik hybrid ini berkisar antara 2.4- $2.8 \mathrm{kWh}$ per hari. Energi yang dapat dihasilkan dari sistem yang berada di P. Kapo - Kapo adalah kira - kira dua kali lipat dibandingkan dengan sistem yang dipasang di kantor gubernur. Bila kita pisahkan, rata rata satu sistem di Kantor Gubernur dapat menghasilkan energi total per hari sebesar 2.5 kWh, sedangkan di P. Kapo - Kapo sebesar 2.8 kWh.

Tujuan dari pengembangan sistem ini adalah untuk menerangi daerah - daerah terpencil yang belum punya akses listrik. Umumnya, pada daerah tersebut kebutuhan listrik tidak sebesar masyarakat di pulau besar. Dengan asumsi satu rumah menggunakan 5 lampu $10 \mathrm{~W}$ untuk dinyalakan selama 12 jam, dan TV $100 \mathrm{~W}$ selama 4 jam, energi total 
yang dibutuhkan per hari adalah $1 \mathrm{kWh}$. Oleh karena itu, satu sistem pembangkit listrik hybrid minimal dapat memenuhi kebutuhan listik satu atau dua rumah.

Tabel 4. Energi Yang Dapat Dihasilkan Sistem

\begin{tabular}{|c|c|c|}
\hline No & Tanggal & Energi yang dihasilkan (Kwh) \\
\hline 1 & $01 / 11 / 2018$ & 2.489 \\
\hline 2 & $02 / 11 / 2018$ & 2.496 \\
\hline 3 & $03 / 11 / 2018$ & 2.522 \\
\hline 4 & $12 / 11 / 2018$ & 2.567 \\
\hline 5 & $13 / 11 / 2018$ & 2.567 \\
\hline 6 & $14 / 11 / 2018$ & 2.653 \\
\hline 7 & $22 / 11 / 2018$ & 2.884 \\
\hline 8 & $23 / 11 / 2018$ & 2.564 \\
\hline 9 & $27 / 11 / 2018$ & 2.790 \\
\hline 10 & $28 / 11 / 2018$ & 2.550 \\
\hline
\end{tabular}

Dengan adanya pemanfaatan sistem pembangkit listrik hybrid ini, warga , yang sebelumnya sudah mempunyai akses listrik dari PLN, tidak lagi harus membayar listrik kepada PLN. Keuntungan tersebut dapat dihitung dari perkalian antara energi total yang dapat dihasilkan dengan harga listrik di Indonesia. Tabel di bawah menampilkan harga listrik yang dapat dihemat per hari dari pemasangan sistem ini.

Tabel 5. Biaya listrik yang dapat dihemat oleh sistem Pembangkit Hybrid

\begin{tabular}{|c|c|c|c|}
\hline NO & Tanggal & $\begin{array}{c}\text { Energi yang } \\
\text { dihasilkan (Kwh) }\end{array}$ & $\begin{array}{c}\text { Harga Listrik yang Dapat } \\
\text { Dihemat (Rp) }\end{array}$ \\
\hline 1 & $01 / 11 / 2018$ & 2.489 & 3646 \\
\hline 2 & $02 / 11 / 2018$ & 2.496 & 3657 \\
\hline 3 & $03 / 11 / 2018$ & 2.522 & 3695 \\
\hline 4 & $12 / 11 / 2018$ & 2.567 & 3761 \\
\hline 5 & $13 / 11 / 2018$ & 2.567 & 3761 \\
\hline 6 & $14 / 11 / 2018$ & 2.653 & 3887 \\
\hline 7 & $22 / 11 / 2018$ & 2.884 & 4225 \\
\hline 8 & $23 / 11 / 2018$ & 2.564 & 3756 \\
\hline 9 & $27 / 11 / 2018$ & 2.790 & 4087 \\
\hline 10 & $28 / 11 / 2018$ & 2.550 & 3736 \\
\hline
\end{tabular}

Dapat terlihat pada dua tabel diatas, bahwa penghematan biaya listrik yang dapat diperoleh dengan pemasangan sistem ini termasuk kecil, yaitu berkisar antara Rp. 3.000 Rp. 4.000 per hari. Hal ini diakbitkan karena tariff listrik di Indonesia masih sangat rendah. Rendahnya tariff ini ditengarai disebabkan oleh masih maraknya pembangkitan listrik dengan tenaga pembakaran batubara. Oleh karena itu, sistem ini ditujukan bukan untuk masyarakat yang sudah punya akses listrik dari PLN, melainkan masyarakat yang belum dapat diterangi oleh PLN. 


\section{KESIMPULAN DAN SARAN}

Kesimpulan dari dokumen studi kelayakan sistem pembangkit listrik hybrid adalah efisiensi system hybrid pada penelitian ini adalah kurang dari $30 \%$, yaitu sebesar $11,2017 \%$. Hal ini menunjukkan PLT Hybrid belum menunjukkan performa yang baik di lihat dari effesiensinya. Secara rinci efisiensi turbin angin pada penelitian ini adalah sebesar 10,769\%dan efisiensi PLTS pada penelitian ini adalah sebesar $11.526 \%$. Kedua pembangkit belum menunjukkan performa yang baik di lihat dari effesiensinya karena kurang dari $30 \%$.

Total energi yang dapat dihasilkan dari sistem pembangkit listrik hybrid per hari adalah $2.7 \mathrm{kWh}$. Sistem masih sangat perlu untuk lebih dikembangkan dari segi umur operasi dan kemudahan pengoperasian, serta perawatan.

Adapun saran yang diperoleh dari pengerjaan studi kelayakan sistem pembangkit listrik hybrid, adalah sistem Hybrid PLTB dan PLTS secara teknis sangat perlu di kembangkan seperti konfigurasi antara batterai, inverter dan kontroler dari system tersebut. Sebaiknya menggunakan instrument pengukuran yang lebih akurat. Pengujian potensi dilakukan dalam rentang waktu yang lebih lama dan pengambilan data sebaiknya dilakukan juga di musim kemarau, guna mendapatkan gambaran performa sistem selama satu tahun.

\section{UCAPAN TERIMAKASIH}

Penulis mengucapkan terima kasih kepada PT Sinergi Nanotech Indonesia yang telah bersedia menerima dilakukannya penelitian di lingkungan perusahaan ini dan menggunakan peralatan yang dimiliki perusahaan.

\section{DAFTAR PUSTAKA}

[1] N. Habibie, A. Sasmito, and Kurniawan, "Kajian Potensi energy Angin di Wilayah Sulawesi dan Maluku," in Jurnal Meteorologi dan Geofisika, vol. 12, pp. 181-187.

[2] G. Trewartha and L. H. T, Pengantar Iklim. Gadjah Mada University Press: Yogyakarta, 1995.

[3] S. Klara, L. H. Abd, U. Baharuddin, and M. Pawara, "Kajian Potensi Energi Angin di Perairan Barat dan Selatan Pulau Sulawesi," in Prosiding Teknik Perkapalan UNHAS, 2013, vol. 7.

[4] A. Fadholi, "Analisis Data Arah Dan Kecepatan Angin Landas Pacu (Runway) Menggunakan Aplikasi Windrose Plot (Wrplot)," in Jurnal Ilmu Komputer, 2013, vol. 9, no. September 2013, p. 2.

[5] Badan meterologi klimatologi dan geofisika, "Prakiraan Angin." [Online]. Available: http://www.bmkg.go.id/cuaca/prakiraan-angin.bmkg. 